\title{
Human Capital and Information and Communication Technology Nexus: The South African Perspective
}

\author{
Itumeleng Pleasure Mongale* and Mahlatse Malebo Lethabo Magongoa
}

\author{
School of Economics and Management, University of Limpopo, South Africa
}

\begin{abstract}
Despite the fact that South Africa invests a considerable amount in education and also the fact that black youth have higher educational attainment now than at any point in history, education which is seen as a process, the outcome of which is general knowledge and human capital is still facing enormous challenges. Using the bounds testing procedure, the study investigated the human capital and information and communication technology (ICT) nexus in South Africa. This was achieved by regressing investment in ICT and ICT infrastructure variables on one of the human capital variables (education). The literature review has revealed that studies on this issue using time series analysis are relatively thin in the context of South Africa. The results revealed that gross fixed capital formation (ICT equipment) has positive relationship with human capital whereas both the mobile cellular subscriptions per 100 people and fixed telephone subscriptions per 100 people have a negative relationship with human capital in South Africa. The policy implication of this study is that economic policies should recognise the importance of ICT in the development of human capital by bringing utilisation of ICT to some far-off locations within a country, to boost human capital development.
\end{abstract}

Keywords: Government expenditure on education, ICT infrastructure, ICT investment, Autoregressive Distributed Lag, South Africa.

\section{INTRODUCTION}

A key differentiating factor between the earlier and the later cases of industrialisation across the world is the presence of a well-educated workforce in conjunction with changing technologies employed in the production process. The rationale behind this contention is that economic and technological growth is closely correlated to the growth of education and the supply of an adequately trained workforce for the proliferation of economic activity (Gupta, n.d.). As a result, the resources allocated to human capital development and the overall role of various institutions in the production of skilled labour for rapid industrialisation should form the core of the strategies of development.

The importance of human capital in economic development was also well captured by Gupta et al., (2013) who determined that South Korea, which has insufficient natural resources for economic growth, has closed this gap by emphasising on human resources and has made great investments in education, science, technology and knowledge. In line with Gupta et al., (2013), Kavurmaci (2018) added that one of the most contributing factors to the high growth performance of South Korea is its intensive investment in human capital. This was achieved through joint efforts of the government, private sector and the universities who committed to the increase in the intellectual

*Address correspondence to this author at the School of Economics and Management, University of Limpopo, South Africa; Tel: +2715 268 3125; Fax: +2715 268 3523; E-mail: itumeleng.mongale@ul.ac.za and skilled workforce of the country which has particularly shown a rapid increase in the country's educational level and academic performance.

There has been several debates and controversies about the relationship between ICT and productivity. Liao et al., (2016) noted that while the greatest increase in productivity has proved to be associated with a particular class of technologies, like the steam engine and electricity setting off a chain of innovation before the 1900s, the question in $21 \mathrm{st}$ century is whether ICT in general and computers, in particular, hold a similar promise in the New Economy. Furthermore, they argued that many questions surrounding the role of ICT in productivity growth remain unresolved. In particular, a surprising amount of disagreement exists concerning the possible multifacets of ICT productivity and the mechanism through which ICT affects productivity growth.

According to Niebel (2018), the additional productivity gains could be triggered by "ICT-related spillovers or network effects" as ICT may lower transaction costs and speed up the process of knowledge creation. These network effects may be more pronounced "when many firms in a region or industry are using similar levels or types of ICT.

Our literature search has discovered that the mainstream of empirical research such as Lee (2011), Delgado et al., (2012), Chang and Shi (2016) and Ahsan and Haque (2017) have focused mainly on the nexus between ICT infrastructure and economic growth. This situation was also noted by Pradhan et al., 
(2015) who lamented that the majority of the empirical literature provides significant support for a positive relationship between ICT infrastructure and economic growth. Therefore, the novelty of the present study is to contribute to such a research gap by providing an empirical analysis on the relationship between human capital and ICT in South Africa. The study is largely contributing from the channels through which ICT investment and infrastructure affect education. Another significance of this type of study is decreed by Nadiri et al., (2018) who posited that the role of modern communication infrastructure in achieving higher rates of economic growth and development is expanding. However, building such infrastructure requires a substantial amount of investment and, therefore, a proper evaluation of their contribution to human capital is crucial for national strategic policy decisions.

Despite the fact that South Africa invests a considerable amount in education and also the fact that black youth have higher educational attainment now than at any point in history, education which according to Figueroa (2015), is seen as a process, the outcome of which is general knowledge and human capital is still facing enormous challenges in this country.

Mlachila and Moeletsi (2019) revealed that South Africa still suffers from significant challenges in the quality of educational achievement by almost any international metric. They argued that the main explanatory factors are complex and multifaceted, and are associated with insufficient subject knowledge of some teachers, history, race, language, geographic location, and socioeconomic status. In a league table of education systems drawn up in 2015 by the Organisation for Economic Cooperation and Development (OECD) club of mainly rich countries, South Africa ranks 75th out of 76 . Another poor performance was demonstrated by low scores in a quadrennial test of Trends in International Mathematics and Science Study sat by 580,000 pupils in 57 countries. Even though there was an improvement since 2011, South Africa was still at or near the bottom of its various rankings (The Ecomomist, 2017).

The major concern with this situation is that educational attainment level is a key factor affecting earning potential and the country's ability to attract industries with high-wage and high-skill jobs. Education is also a key indicator of a world-class workforce that is ready to meet the challenges of the 21 st century. Another concern as noted by Mlachila and Moeletsi (2019) is that low educational achievement contributes to low productivity growth, and high levels of poverty, unemployment, and inequality. Psacharopoulos and Arriagada (1989) also maintained that the low human capital base is the most serious developmental constraint in developing countries. Governments also invest in education in order to raise the skill level of the labour force and, hence, to increase worker productivity and income in society at large.

Therefore, based on the above-mentioned apprehensions by different authors and the situation outlined by the Ecomomist (2017), the analysis of ICT as one of the channels through which education can be affected seems to be crucial. Thus, the purpose of this study was to determine the human capital and ICT nexus in South Africa.

The article is organised as follows. Section 2 presents the theoretical background and findings from earlier research and positions our study in the literature. Section 3 presents the methodological framework, specify the model and data description. Section 4 presents the results and Section 5 concludes.

\section{LITERATURE REVIEW}

The theoretical framework of this study is rooted both on the contemporary theory of the neoSchumpeterian (Schumpeter, 1934 and Pyka and Andersen, 2012) and neoclassical growth theory (Solow, 1956). According to Bahrini and Qaffas (2019), these theories have highlighted the existence of a significant positive relationship between ICT and economic growth. What is important for this study is the fact the theories highlight an important relationship between ICT and the labour force quality. This is based on both Aghaei and Rezagholizadeh (2017) and Bahrini and Qaffas (2019)'s notion that ICT enters as an input into the economic supply in the form of capital and causes the improvement of the production process through deepening capital and making advancements in technology and labour force quality. As a result, ICT creates added value at both the firm and sectoral levels and therefore leads to the improvement of productivity and economic growth at the country level. Furthermore, Aghaei and Rezagholizadeh (2017) added that its output is value added at the three levels, that is, firm, sectoral and the national, and finally, growth in labour force productivity, profit-making and consumer welfare will follow.

Even though the empirical literature showed different results which remain debatable regarding the 
use of ICT and the role of ICT infrastructure; it was well captured by Pradhan et al., (2015) who indicated that it allows closer links between firms, their customers, suppliers, and collaborative partners and also lower geographical barriers. In addition, it helps with the creation of new knowledge and its faster diffusion through a more efficient process of information transformation, both within and between firms and sectors. That being the case, there is a school of thought which argued that the use and investment of ICT especially in developing countries, would not guarantee economic development unless there are complementary factors such as infrastructure, enabling policies, financial development, human capital and product innovation in play (Sassi and Goaied, 2013; Jin and Cho, 2015).

Ramlan and Ahmed (2009) who used total employment to represent human capital contended that it is synonymous to knowledge accumulation, thus significant in the development of the ICT and long-run economic growth in Malaysia. A similar study by Duasa and Jais (2018) adopted the Autoregressive Distributed Lag (ARDL) cointegration technique to investigate the relationship between economic growth and human capital in Malaysia. In this case, human capital was proxied by education expenditure whereas ICT was denoted by numbers of fixed-line subscribers. They discovered that in the long run, economic growth was positively determined by capital, labour, ICT and human capital however in the short run, only labour, capital and ICT contributed positively and significantly to economic growth but human capital negatively affected growth.

Hofman et al., (2016) are of the opinion that the main cause that the labour productivity gap remains is the widening gap in ICT capital that counteracts improvements in human capital in Latin America. They argued that the role of ICT has been very low, representing less than one-sixth of the total capital contribution. Their analysis by economic activity, using the LA-KLEMS database for Argentina, Brazil, Chile, Colombia, and Mexico, showed that the contribution of capital was the main source of growth in the fastest growing industry, the transportation industry, and communications, and went hand in hand with high investment, especially in ICT.

A study by Niebel (2018) comparing developing, emerging and developed countries ICT and economic growth found that for the combined sample of all 59 countries, the estimated output elasticity of ICT is larger than the ICT factor compensation share suggesting excess returns to ICT capital. The regressions for the subsamples of developing, emerging and developed countries do not reveal statistically significant differences in the output elasticity of ICT between these three groups of countries. Thus, the results indicated that developing and emerging countries are not gaining more from investments in ICT than developed economies, calling into question the argument that these countries are 'leapfrogging' through ICT.

In a similar study done earlier, Dewan and Kraemer (2000) found a positive effect of the ICT capital stock on GDP growth in developed countries, whereas the ICT coefficient for developing countries is insignificant. The authors explain this finding through potentially missing 'IT-enhancing complementarity factors' like human capital. The estimation was accomplished with a panel of 36 countries (14 developing and 22 developed countries) for the years 1985-1993. They noted that, as this period represented the beginning of the rapid diffusion of ICT in developed countries, it was probably too early to see any economically significant effects in developing countries.

Another study which involved ICT infrastructure was conducted by Let et al., (2018) in Malaysia. They examined the impact of ICT adoption on productivity in developed and developing countries. Their findings revealed that ICT adoption drives labour productivity in developed countries, despite the high mobile broadband prices. There is also an indication that people enjoy being connected regardless of the increase in the price of broadband, in order to enhance their productivity. However, it was observed that ICT adoption has an insignificant impact on productivity in the developing countries which were also found to have larger inputs of labour and capital which increased their productivity. This suggests that the impact of ICT might be influenced by a level of economic development in different regions.

Čadil et al., (2014) used endowment in the base year, a ratio of employees with tertiary education on the total number of employees in the region as a proxy of human capital but they could not claim human capital being a positive factor of growth in the European Union regions during the selected period. On the contrary, especially in agricultural regions, they saw a negative effect of human capital endowment on growth but also on unemployment. One of the reasons for such results was attributed to several factors such as highly 
Table 1: Variables and Sources Data

\begin{tabular}{|c|c|c|c|}
\hline Variables & Acronym & Unit & Sources of data \\
\hline Total government expenditure: Education & $T_{G E} E_{\text {Edu }}$ & $\mathrm{R}$ millions & South African Reserve Bank \\
\hline $\begin{array}{l}\text { Gross fixed capital formation: Information, computer and } \\
\text { telecommunications equipment }\end{array}$ & GFCF ICT & R millions & South African Reserve Bank \\
\hline Mobile cellular subscriptions per 100 people & MCS100 & & Federal Reserve Bank of St. Louis \\
\hline Fixed telephone subscriptions per 100 people & FTS100 & & Federal Reserve Bank of St. Louis \\
\hline
\end{tabular}

educated population living in agricultural regions partly works elsewhere in near urbanized regions.

On the other hand, Chang and Shi (2016) argued that it cannot simply take an expansion of the introduction of technology as well as digestion and absorption of expenditure to solve the problem in the digestion and absorption capacity of the high-tech industry but should increase investment in education to enhance human capital in technology backwardness.

\section{RESEARCH METHOD}

We used the ARDL approach to estimate the link between human capital and ICT nexus in South Africa. The approach was found to be relevant because of its ability to generate robust and reliable results even if the sample size is small like in the case of this study (Zafeiriou and Azam, 2017). ARDL model is an ordinary least square (OLS) based model which is applicable for both non-stationary time series as well as for times series with mixed order of integration (Shrestha and Bhatta, 2018).

\subsection{Data and Model Specification}

The study used annual times series data obtained from various sources (see Table 1) covering the period 1989 to 2017. The choice of the variables was underpinned by three models which Lucas (1988) regards as the main features of economic development, that is; a model emphasising physical capital accumulation and technological change; a model emphasising human capital accumulation through schooling and a model emphasising specialised human capital accumulation through learning-by-doing. Finally, following Lucas's (1988) postulation that what really affects economic growth is educated and skilled labour force (knowledge-based labour force), the study hypothesised that ICT investment and ICT infrastructure are channels through which education can be affected in South Africa.

According to Pradhan et al., (2017), ICT infrastructure encompasses digital telephone networks, mobile phones, internet capability, internet servers and fixed broadband and other technologies. Based on the availability of data, the following variables were selected for this study; fixed telephone subscriptions per 100 people and mobile cellular subscriptions per 100 people as proxies of ICT infrastructure. In addition, Gross fixed capital formation: ICTs equipment was introduced to capture the effects of ICT investment on human capital in South Africa. A further explanation of the nature of variables and the sources of data used in this study are presented in Table $\mathbf{1}$ as follows;

In order to achieve the aim of the study, human capital as a function of ICT infrastructure was investigated by applying the following regressions:

$$
T G E_{\text {Edut }}=\beta_{0}+\beta_{1} G F C F_{\text {ICT }}+\beta_{2} M_{C S 100}+\beta_{3} F T S 100_{t}+\mu_{t} 1
$$

Since economic time series variables tend to be nonstationary, the characteristics of the time-series data used in this study were assessed through unit root tests. This was followed by the long and the short run analyses of the model. To determine their robustness, the model was also taken through a battery of diagnostic and stability tests.

\subsection{Empirical Analysis}

The following econometric procedures were undertaken to determine the relationship between human capital and ICT in South Africa.

\subsubsection{Unit Root Test}

Most of economic time-series data are likely to be non-stationary. If a time series is found to be nonstationary, a filtering mechanism such as the first difference of the variable can be employed to induce stationarity for univariate model estimation (Lee, 2011). This process is deemed to be necessary because based on the unit root hypothesis some variables would not be stationary and random shocks would affect their long run position. In other words, to explain some features of a series we need to know whether or not it has a unit root (Guaita, 2016). 
The study used the Augmented Dickey-Fuller (ADF) and the Dickey-Fuller Generalized Least Squares (DFGLS) unit root tests. The ADF test is regarded as one of the best known and most widely used unit root tests (Arltova and Fedorová, 2016) and DFGLS is another one of its modifications that were used as a confirmatory test. Based on Elliott et al., (1996), the advantage of DFGLS test is that it has more power than a Dickey-Fuller test when an unknown trend or mean is present.

\subsubsection{ARDL Bounds Test for Cointegration}

In order to analyse both the long run and short run dynamic interactions among the variables of interest, we employed the ARDL cointegration technique developed by Pesaran et al., 2001. Despite its numerous advantages, this technique was preferred mainly because according to Harris and Sollis (2003), it is relatively more efficient in the case of small and finite sample data sizes and for the fact that it obtains unbiased estimates of the long run model.

The ARDL model is specified as follows:

$$
\begin{aligned}
& \Delta I n T G E_{\text {Edut }}=\beta_{0}+\sum_{i=1}^{m} \beta_{1} \Delta I n T G E_{E d u t-i}+\sum_{i=1}^{m} \beta_{2} \Delta I n G F C F_{\text {ICT } t-i}+\sum_{i=1}^{m} \beta_{3} \Delta M C S 100_{t-1} \\
& +\sum_{i=1}^{m} \beta_{4} \Delta F T S 100_{t-i}+\alpha_{1} \operatorname{InTGE} E_{E d u t-1}+
\end{aligned}
$$

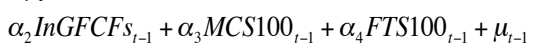

where $\Delta$ is the first difference operator, TGE is the dependent variable, GFCF, MCS100 and FTS100 are the regressors as indicated in Table 1. Furthermore, $\beta_{1}$ to $\beta_{4}$ and correspond to the long run parameters and $\mu$ is the white noise error term.

The F-test will be conducted to investigate the existence of cointegration or long run economic relationship among the variables. The null hypothesis of having no cointegration, $\mathrm{H}_{0}: \beta_{1}=\beta_{2}=\beta_{3}=\beta_{4}=0$ is tested against the alternative hypothesis, $\mathrm{H}_{1}: \beta_{1} \neq \beta_{2}$ $\neq \beta_{3} \neq \beta_{4} \neq 0$. If the null hypothesis is rejected it means, the existence of long run relationship amongst the variables in the model and an error correction model will be estimated from the following equation:

$$
\begin{aligned}
& \Delta I n T G E_{E d u t}=\beta_{0}+\sum_{i=1}^{m} \beta_{1} \Delta I n T G E_{E d u t-i}+\sum_{i=1}^{m} \beta_{2} \Delta I n G F C F_{I C T t-i}+ \\
& \sum_{i=1}^{m} \beta_{3} \Delta M C S 100_{t-1}+\sum_{i=1}^{m} \beta_{4} \Delta F T S 100_{t-i}+\beta_{6} E C T_{t-i}+\mu_{t}
\end{aligned}
$$

where the value of the ECT will indicate the reversion and speed of adjustment to reach equilibrium. Finally, the model will be taken through a battery of both the diagnostic and stability tests to ensure its goodness of fit.

\subsubsection{Diagnostic and Stability Tests}

Diagnostic and stability tests are also known as misspecification testing. According to Seddighi et al., (2000), these tests do not involve a specific alternative form of the model. They are essentially used to detect an indicate specification. They only tell us that a particular assumption under consideration is inadequate or cannot be confirmed, but how to correct the inadequacy is left to the practitioner. Diagnostic testing is done to determine whether any of the assumptions of the classical normal linear regression model are violated; in other words, to examine the "goodness of fit" of the model, that is, how well the model actually meets the assumptions (Casson and Farmer, 2014). In the same vein, the stability test of the regression parameters is also undertaken using the Brown et al., (1975) stability testing technique. This is based on the conception that the regression analysis of time series data is usually based on the assumption that the regression relationship is constant over time. Therefore, the validity of this assumption is open to question in some applications particularly in a field such as economics, and it is often desirable to examined particularly if the model is to be used for forecasting (Brown et al., 1975).

\section{EMPIRICAL RESULTS AND DISCUSSION}

This section presents the results and analyses of all the estimation techniques performed in this study.

\subsection{Unit Root/Stationarity}

The unit root tests result in Tables 2 and $\mathbf{3}$ indicate that all the variables were nonstationary at levels and stationarity was found at first difference.

\subsection{Cointegration Analysis Results}

Since there was no I(2) variable in the model, the bounds procedure to test whether there is a cointegration relationship between the human capital and the ICT infrastructure was employed. We found evidence of the presence of the long run relationship amongst the variables and the results are presented in Table 4.

The results in Table 4 indicate that the estimated Fstatistics of 4.875275 is higher than both the lower and upper bounds critical values at 1,5 and 10 per cent's 
Table 2: ADF Test Results

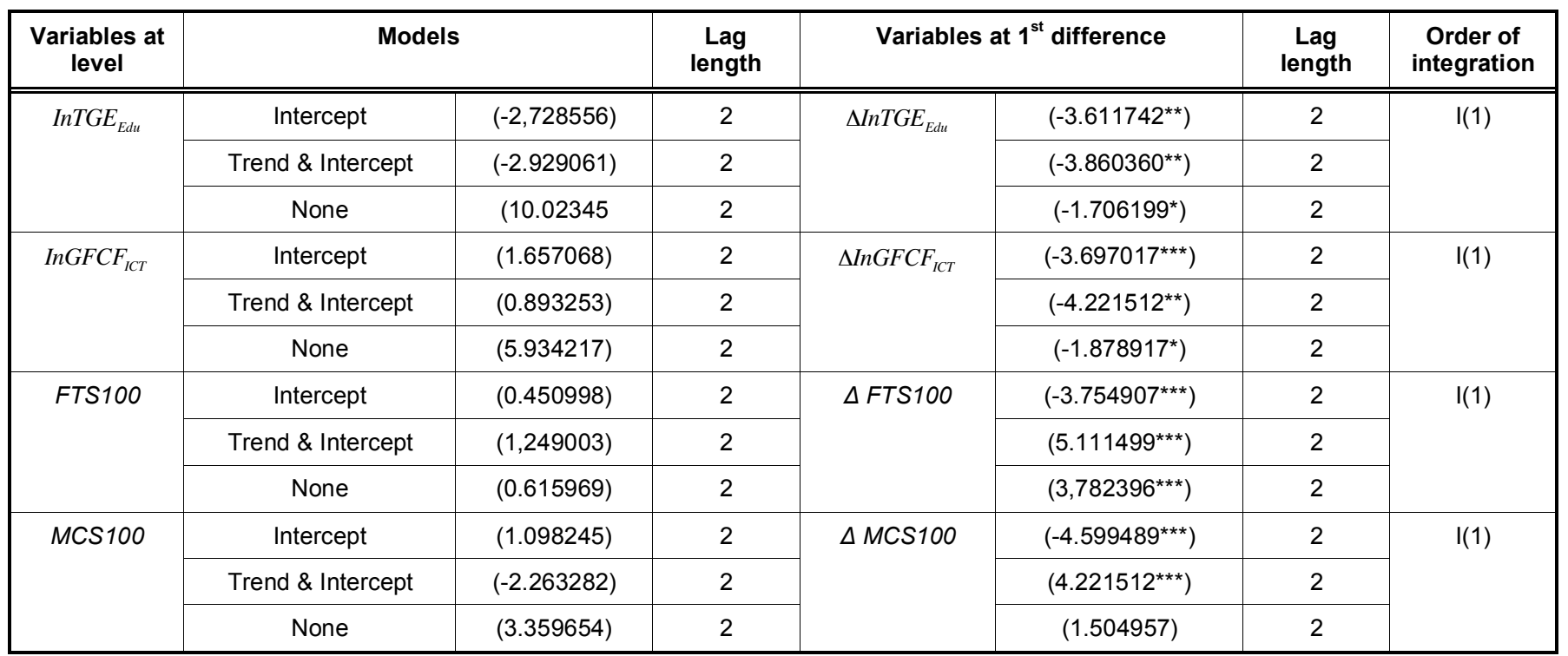

Notes: The values in brackets are the t-statistics of corresponding estimated coefficients, and ${ }^{* * *},{ }^{* *}$ and * denote significance at $1 \%, 5 \%$ and $10 \%$, respectively

I(1) Indicates unit root at first difference being stationary.

$\mathrm{I}(0)$ Indicates unit root in the level being stationary.

$\Delta$ Indicates changes at first difference.

Indicates critical value at $5 \%$ significance level.

Table 3: DF-GLS Test Results

\begin{tabular}{|c|c|c|c|c|c|c|c|}
\hline Variables at & \multicolumn{2}{|c|}{ Models } & Lag & \multicolumn{2}{|c|}{ Variables at $1^{\text {st }}$ difference } & \multirow{2}{*}{$\begin{array}{c}\begin{array}{c}\text { Lag } \\
\text { length }\end{array} \\
2\end{array}$} & \multirow{2}{*}{$\begin{array}{c}\begin{array}{c}\text { Order of } \\
\text { integration }\end{array} \\
\mathrm{I}(1)\end{array}$} \\
\hline $\operatorname{InTGE_{Edu}}$ & Intercept & $(0.308468)$ & 2 & $\Delta I n T G E_{E d u}$ & $\left(-3.118866^{\star * *}\right)$ & & \\
\hline \multirow[t]{2}{*}{$I n G F C F_{I C T}$} & Intercept & $(-0.546495)$ & 2 & \multirow[t]{2}{*}{$\triangle I n G F C F_{I C T}$} & $\left(-3.176971^{\star \star \star}\right)$ & 2 & \multirow[t]{2}{*}{$\mathrm{I}(1)$} \\
\hline & Trend \& Intercept & $(-1.072576)$ & 2 & & $\left(-3.885090^{* * *}\right)$ & 2 & \\
\hline FTS100 & Trend \& Intercept & $(-1.286853)$ & 2 & $\triangle F T S 100$ & $\left(-5,248175^{\star \star *}\right)$ & 2 & $\mathrm{I}(1)$ \\
\hline \multirow[t]{2}{*}{ MCS100 } & Intercept & $(-0.649519)$ & 2 & \multirow[t]{2}{*}{$\triangle M C S 100$} & $\left(-4.517115^{\star \star *}\right)$ & 2 & \multirow[t]{2}{*}{$\mathrm{I}(1)$} \\
\hline & Trend \& Intercept & $(1.662411)$ & 2 & & $\left(-5172743^{* * *}\right)$ & 2 & \\
\hline
\end{tabular}

Notes: The values in brackets are the t-statistics of corresponding estimated coefficients, and ${ }^{* * *},{ }^{* *}$ and ${ }^{*}$ denote significance at $1 \%, 5 \%$ and $10 \%$, respectively.

I(1) Indicates unit root at first difference being stationary.

$\mathrm{I}(0)$ Indicates unit root in the level being stationary.

$\Delta$ Indicates changes at first difference.

"** Indicates critical value at $5 \%$ significance level.

Table 4: F-Statistics for Cointegrating Relationship

\begin{tabular}{|c|c|c|c|c|}
\hline \multirow{2}{*}{ Test statistics } & Value & Significance levels & \multicolumn{2}{|c|}{ Bounds Critical values } \\
\hline \hline F-statistic & 4.875275 & $\%$ & $\mathrm{I}(0)$ & $\mathrm{I}(1)$ \\
$\mathrm{K}$ & 3 & $1 \%$ & 3.65 & 2.79 \\
& & $5 \%$ & 2.27 & 3.66 \\
& & $10 \%$ & 4.66 & \\
\hline
\end{tabular}

significant levels. This indicates that the null hypothesis of no cointegration among variables is rejected at the three levels of significant, hence the cointegration among the variables was established. 
Table 5: Estimated Long Run Model

\begin{tabular}{|c|c|c|c|}
\hline \multicolumn{2}{|c|}{ Dependent variable } & \multicolumn{3}{|c|}{ Regressors } \\
\hline \hline InTGE $E_{E d u}$ & InGFCF $F_{I C T}$ & MCS100 & FTS100 \\
& 1.044033 & -0.004216 & -0.095474 \\
\cline { 2 - 4 } & $(0.445584)$ & $(0.004615)$ & $(0.065935)$ \\
\hline
\end{tabular}

Note: standard error in parentheses; ${ }^{* *}$ significant at $5 \%$; ${ }^{*}$ significant at $10 \%$.

\subsubsection{Long Run Relationship Analyses}

The results of the long run model which was developed by normalizing on total government expenditure in education are presented in Table $\mathbf{5}$. MCS100 is the only significant variable which appears to have effects on human capital in South Africa. On the other hand, GFCF ICT was found to be positively related to $\mathrm{TGE}_{\mathrm{Edu}}$ whereas both the MCS100 and FTS100 have a negative relationship with $\mathrm{TGE}_{\mathrm{Edu}}$. The implications are that a 1 per cent increase in gross fixed capital formation (ICT equipment) leads to a more 100 per cent increase in human capital whereas a 1 per cent growth in both mobile cellular subscriptions per 100 people and fixed telephone subscriptions per 100 people lead to a decline of about 0.4 and 10 per cent's respectively.

\subsubsection{Short Run Relationship Analysis}

The results ECM presented in Table 6 shows that the coefficient of an error correction term $\left(E C T_{t-1}\right)$ is significant and negative which provides the evidence of causality in at least one direction. The coefficient of 0.164216 indicates the rate of convergence to equilibrium. Any deviation from the long run equilibrium is corrected at about 16 per cent for each period to return to the long run equilibrium level.

\subsection{Diagnostic and Stability Tests Results}

The diagnostic tests in the model indicate no evidence of serial correlation or heteroskedastic problems. The model also passed the Jarque-Bera normality test which indicates that the error terms are normally distributed. Likewise, the model was found to be stable throughout the period of study as indicated by the Ramsey RESET test and also by the plots of residuals of both the CUSUM and CUSUM of Squares outputs in Figure 1 which remained within the critical lines of 5 per cent through the entire period of the investigation.

\section{CONCLUDING REMARKS}

The study examined the relationship between human capital and ICT in South Africa. Before the long and the short run analyses tests were made, the unit root tests were performed to assess the stability of the time series data. All the variables were found to be nonstationary at levels but their first differences were found to be stable. The bounds cointegration was employed to determine whether a stable linear combination exists between the variables and the cointegration relationship was established in the model.

Table 6: Error Correction Model for Human Capital

\begin{tabular}{|c|c|c|}
\hline \multicolumn{3}{|c|}{ Dependent variable: $\operatorname{In} T G E_{E d u}$} \\
\hline Regressors & Coefficient & t-statistic \\
\hline $\mathrm{D}\left(\operatorname{InTGE} E_{E d u}(-1)\right)$ & 0.157665 & 1.142220 \\
\hline $\mathrm{D}\left(\operatorname{InTGE_{Edu}}(-2)\right)$ & 0.504222 & 3.867360 \\
\hline$D\left(\operatorname{InGFCF_{ICT}}\right)$ & 0.131947 & 1.896416 \\
\hline$D\left(\operatorname{InGFCF_{ICT}}(-1)\right)$ & 0.157665 & -2.899976 \\
\hline$D\left(\operatorname{InGFCF_{ICT}}(-2)\right)$ & 0.504222 & -2.311131 \\
\hline $\mathrm{D}(\mathrm{MCS} 100)$ & -0.001751 & -3.927174 \\
\hline ECT & -0.164216 & -5.556684 \\
\hline
\end{tabular}


Table 7: Summary of Diagnostic and Stability Tests Results

\begin{tabular}{|c|c|c|c|}
\hline Diagnostic analysis & Test & P-value & Conclusion \\
\hline Serial correlation & LM & 0.6489 & Accept $\mathrm{H}_{0}$ \\
\hline Heteroscedasticity & $\mathrm{ARCH}$ & 0.7442 & Accept $\mathrm{H}_{0}$ \\
\hline Normality & $\mathrm{JB}$ & 0.334638 & Accept $\mathrm{H}_{0}$ \\
\hline \multicolumn{4}{|l|}{ Stability analysis } \\
\hline Ramsey RESET & & 0.1320 & Accept $\mathrm{H}_{0}$ \\
\hline
\end{tabular}

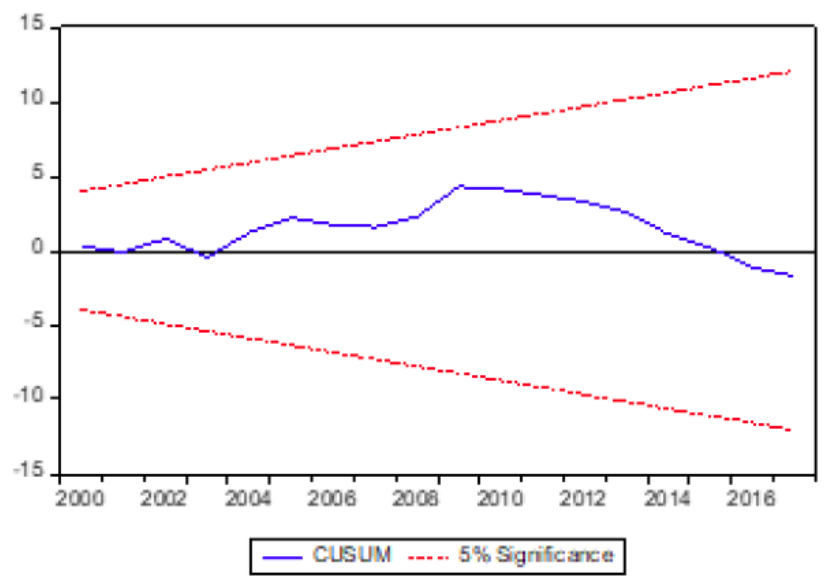

Figure 1: CUSUM and CUSUM of Squares.

The present study contributed to the established research gap by providing a piece of empirical evidence on the relationship between human capital and ICT in the South African context. The results revealed that gross fixed capital formation (ICT equipment) has positive relationship human capital whereas both the mobile cellular subscriptions per 100 people and fixed telephone subscriptions per 100 people have a negative relationship with human capital in South Africa.

The outcome of a positive association between ICT equipment and human capital is in line with Pradhan et al., (2015) who noted that ICT helps with the creation of new knowledge and its faster diffusion through a more efficient process of information transformation. Borrowing from Let et al., (2018) the negative association between human capital and other proxies of ICT infrastructure might be a justification for South African policymakers to subsidize bringing utilisation of ICT to some far-off locations within a country, so as to boost human capital development because this might enable citizens to increase the adoption of ICT without having to worry about increasing cost.

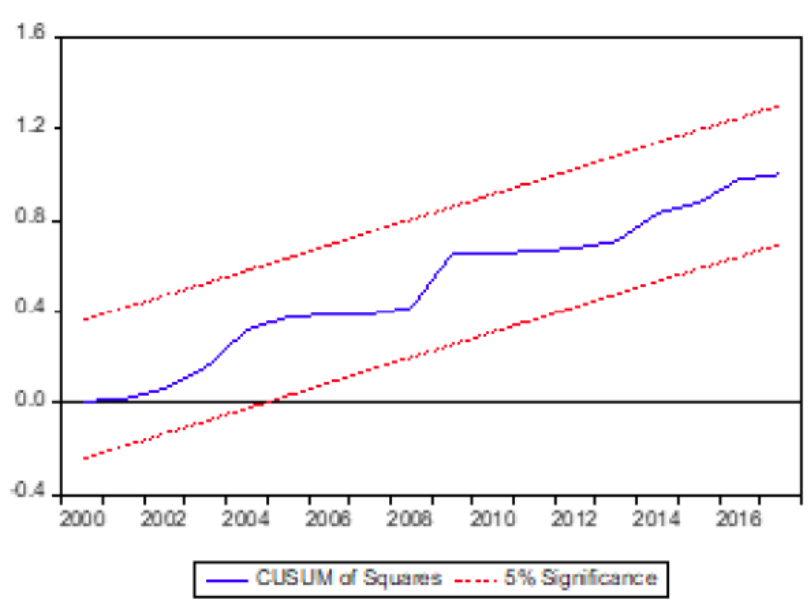

\section{REFERENCES}

Aghaei, M. and Rezagholizadeh, M. (2017), 'The impact of information and communication technology (ICT) on economic growth in the OIC countries', Economic and Environmental Studies, Vol. 17 No. 2, pp. 255-276. https://doi.org/10.25167/ees.2017.42.7

Ahsan, H. and Haque, M.E. (2017), 'Threshold effects of human capital: Schooling and economic growth', Economics Letters, North-Holland, Vol. 156, pp. 48-52. https://doi.org/10.1016/j.econlet.2017.04.014

Arltova, M. and Fedorová, D. (2016), 'Selection of unit root test on the basis of length of the time series and value of $\operatorname{ar}(1)$ parameter', Statistika, Vol. 96 No. 3, pp. 47-64.

Bahrini, R. and Qaffas, A.A. (2019), 'Impact of information and communication technology on economic growth: Evidence from developing countries', Economies, Vol. 7 No. 1. https://doi.org/10.3390/economies7010021

Brown, R, Durbin, J. and Evans, J. (1975), 'Techniques for Testing the Constancy of Regression Relationships over Time', Journal of the Royal Statistical Society, Vol. 37 No. 2, pp. 149-192. https://doi.org/10.1111/j.2517-6161.1975.tb01532.x

Čadil, J., Petkovová, L. and Blatná, D. (2014), 'Human Capital, Economic Structure and Growth', Procedia Economics and Finance, Elsevier, Vol. 12, pp. 85-92. https://doi.org/10.1016/S2212-5671(14)00323-2

Casson, R.J. and Farmer, L.D. (2014), 'Understanding and checking the assumptions of linear regression: a primer for medical researchers', Clinical \& Experimental Ophthalmology, Vol. 42 No. 6, pp. 590-596. https://doi.org/10.1111/ceo.12358 
Chang, X. and Shi, Y. (2016), 'The Econometric Study on Effects of Chinese Economic Growth of Human Capital', Procedia Computer Science, Elsevier Masson SAS, Vol. 91 pp. 10961105.

https://doi.org/10.1016/j.procs.2016.07.160

Delgado, M.S., Henderson, D.J. and Parmeter, C.F. (2012), Does Education Matter for Economic Growth? Does Education Matter for Economic Growth ? Bonn.

Duasa, J. and Jais, N.M. (2018), 'Information communication technology, human capital and economic growth in Malaysia: an empirical analysis', The Turkish Online Journal of Design, Art and Communication-TOJDAC, Vol. Special Ed, pp. 14151419.

Elliott, G., Rothenberg, T.J., Stock, J.H.J., Eliiot, G., Rothernberg, T.J. and Stock, J.H.J. (1996), 'Efficient Tests for an Autoregressive Unit Root', Econometrica, Vol. 64 No. 4, p. 813 https://doi.org/10.2307/2171846

Figueroa, A. (2015), 'Education and Human Capital Formation', Growth, Employment, Inequality, and the Environment, Palgrave Macmillan, New York, pp. 11-27. https://doi.org/10.1057/9781137506979_2

Guaita, S. (2016), 'Revisiting the Unit Root Hypothesis: A Historical and Empirical Study', New School Economic Review, Vol. 8 No. March, pp. 59-78

Gupta, A. (n.d.). Technology Accumulation and Education in South Korea, available at https://www.academia.edu/39664029.

Gupta, N., Healey, D.W., Stein, A.M. and Shipp, S.S. (2013), Innovation Policies of South Korea, Virginia.

Harris, R.I.D. and Sollis, R. (2003), Applied Time Series Modelling and Forecasting, J. Wiley, available at https://www.wiley.com/en-

us/Applied+Time+Series+Modelling+and+Forecasting-p9780470844434 (accessed 9 July 2019).

Hofman, A., Aravena, C. and Aliaga, V. (2016), 'Information and communication technologies and their impact in the economic growth of Latin America, 1990-2013', Telecommunications Policy, Vol. 40 No. 5, pp. 485-501. https://doi.org/10.1016/j.telpol.2016.02.002

Jin, S. and Cho, C.M. (2015), 'Is ICT a new essential for national economic growth in an information society?', Government Information Quarterly, Vol. 32 No. 3, pp. 253-260. https://doi.org/10.1016/i.giq.2015.04.007

Kavurmaci, A. (2018), 'The Place of R \& D and Education Policies in South Korea's Economic Development', Sosyal Siyaset Konferansları Dergisi, Vol. 74, pp. 51-64.

Lee, J.-W. (2011), 'Empirical Evidence of Causality Between Information Communications Technology and Economic Growth in China, Japan and South Korea', The 11th International DSI and the 16th APDSI Joint Meeting, Taipei, available at http://data.worldbank.org/ (accessed 4 July 2019).

Let, H.S., Hamzah, H., Yusop, Z. and Mazlan, N.S. (2018), 'ICT Adoption Drives Productivity in Developed and Developing Countries', Jurnal Ekonomi Malaysia, Vol. 52 No. 3, pp. 217230

Liao, H., Wang, B., Li, B. and Weyman-Jones, T. (2016), 'ICT as a general-purpose technology: The productivity of ICT in the United States revisited', Information Economics and Policy, Vol. 36, pp. 10-25. https://doi.org/10.1016/j.infoecopol.2016.05.001

Lucas, R.E. (1988), On the Mechanics of Economic Development, Journal of Monetary Economics, Vol. 22. https://doi.org/10.1016/0304-3932(88)90168-7
Mlachila, M. and Moeletsi, T. (2019), 'Struggling to Make the Grade: A Review of the Causes and Consequences of the Weak Outcomes of South Africa's Education System', IMF Working Papers, Vol. 19 No. 47, p. 1. https://doi.org/10.5089/9781498301374.001

Nadiri, M.I., Nandi, B. and Akoz, K.K. (2018), 'Impact of modern communication infrastructure on productivity, production structure and factor demands of US industries: Impact revisited', Telecommunications Policy, Vol. 42 No. 6, pp. 433-451. https://doi.org/10.1016/j.telpol.2018.03.008

Niebel, T. (2018), 'ICT and economic growth - Comparing developing, emerging and developed countries', World Development, Pergamon, Vol. 104, pp. 197-211. https://doi.org/10.1016/i.worlddev.2017.11.024

Pesaran, M.H., Shin, Y. and Smith, R.J. (2001), 'Bounds testing approaches to the analysis of level relationships', Journal of Applied Econometrics, Vol. 16 No. 3, pp. 289-326. https://doi.org/10.1002/jae.616

Pradhan, R.P., Arvin, M.B., Bahmani, S. and Bennett, S.E. (2017), 'The innovation- growth link in OECD countries: Could other macroeconomic variables matter?', Technology in Society, Vol. 51, pp. 113-123. https://doi.org/10.1016/j.techsoc.2017.08.003

Pradhan, R.P., Arvin, M.B. and Norman, N.R. (2015), 'The dynamics of information and communications technologies infrastructure, economic growth, and financial development: Evidence from Asian countries', Technology in Society, Vol. 42, pp. 135-149. https://doi.org/10.1016/j.techsoc.2015.04.002

Psacharopoulos, G. and Arriagada, A.M. (1989), 'The determinants of early age human capital formation: evidence from Brazil', Economic Development \& Cultural Change, Vol. 37 No. 4, pp. $683-708$ https://doi.org/10.1086/451755

Pyka, A. and Andersen, E.S. (2012), 'Introduction: long term economic development - demand, finance, organization, policy and innovation in a Schumpeterian perspective', Journal of Evolutionary Economics, Vol. 22 No. 4, pp. 621625. https://doi.org/10.1007/s00191-012-0279-z

Ramlan, J. and Ahmed, E.M. (2009), 'Information and Communication Technology (ICT) and human capital management trend in Malaysia's economic development', Applied Economics Letters, Vol. 16 No. 18, pp. 1881-1886. https://doi.org/10.1080/13504850701719637

Sassi, S. and Goaied, M. (2013), 'Financial development, ICT diffusion and economic growth: Lessons from MENA region', Telecommunications Policy, Vol. 37 No. 4-5, pp. 252-261. https://doi.org/10.1016/j.telpol.2012.12.004

Schumpeter. (1934), The Theory of Economic Development: An Inquiry Into Profits, Capital, Credit - Joseph Alois Schumpeter - Google Books, available at https://books.google.co.za/books? (accessed 27 November 2019).

Seddighi, H.R., Lawler, K.A., Lawler, K. and Katos, A. V. (2000) Econometrics: A Practical Approach, Routledge, London (accessed 30 January 2020).

Shrestha, M.B. and Bhatta, G.R. (2018), 'Selecting appropriate methodological framework for time series data analysis', The Journal of Finance and Data Science, Elsevier Ltd, Vol. 4 No. 2, pp. 71-89. https://doi.org/10.1016/j.jfds.2017.11.001

Solow, R.M. (1956), A Contribution to the Theory of Economic Growth, Source: The Quarterly Journal of Economics, Vol. 70. https://doi.org/10.2307/1884513 
The Ecomomist. (2017), 'South Africa has one of the world's worst education systems - South Africa's schools', The Economist, available at https://www.economist.com/middle-east-andafrica (accessed 25 January 2019).
Zafeiriou, E. and Azam, M. (2017), 'CO2 emissions and economic performance in EU agriculture: Some evidence from Mediterranean countries', Ecological Indicators, Vol. 81, pp. 104-114.

https://doi.org/10.1016/j.ecolind.2017.05.039

DOI: https://doi.org/10.6000/1929-7092.2020.09.38

(C) 2020 Mongale and Magongoa; Licensee Lifescience Global.

This is an open access article licensed under the terms of the Creative Commons Attribution Non-Commercial License (http://creativecommons.org/licenses/by-nc/3.0/) which permits unrestricted, non-commercial use, distribution and reproduction in any medium, provided the work is properly cited. 